\author{
Maria H. Petkova* \\ Plovdiv University, Bulgaria
}

\title{
HUMOR COMPETENCE IN ENGLISH AS A SECOND OR FOREIGN LANGUAGE
}

\begin{abstract}
Developing humor competence in a second or foreign language is difficult, but it is very important for successful intercultural communication. The nature of humor and its sociocultural functions make humor competence one of the last hurdles even advanced language learners often struggle to overcome. Since types of humor and attitudes towards joking are different in different cultures and humor comprehension requires a complex combination of linguistic and cultural knowledge, second or foreign language teachers need to help their students with this often-neglected area of pragmatics. In social, academic, and professional settings, humor can relieve tension, exert social control, and enhance social cohesion, delineating who belongs or does not belong in a particular group. As humor can function both as a cultural divide and a unifying factor, the time has come to include some type of humor competency training in second or foreign language education. Based on humor research and research in teaching English as a second or foreign language, more and more educators are beginning to experiment with, document, and evaluatethe results of various strategies and approaches to teaching with and about humor in English.
\end{abstract}

Keywords: humor, humor competence, teaching English as a second language, teaching English as a foreign language, pragmatics.

Humor is inherently difficult for even advanced learners to understand and produce in a second or foreign language (Bell, 2007; Vega, 1990). In spontaneous conversation, its complex nature involves multiple, often hybrid types of humor serving several overlapping semantic or pragmatic functions and marked by various verbal and non-verbal cues. It requires English language learners to understand, among other features, the syntax, vocabulary, connotations, socio-cultural background, and appropriate contexts for joking in English conversation. Never the less, humor in natural interaction is a vital tool for socialization, negotiations, and even workplace success. Not many English as a second language (ESL) or English as a foreign language (EFL) textbooks and programs, however, offer systematic training in this area of pragmatics (Claire, 1984). A growing number of ESL/EFL

*mpetkova@uni-plovdiv.bg 
teachers and researchers, therefore, are beginning to investigate and document ways to teach humor competence in cross-cultural communication (Lucas, 2005; Rucynski, 2017; Rucynski \& Prichard, 2020).

\section{WHAT IS HUMOR?}

There are numerous different definitions of humor accepted in various historical, geographical and cultural realms. In addition, several different scholarly disciplines have studied humor and defined it for each particular discipline, ranging from biology and the theory of evolution to psychology, literature and folklore, to mention just a few. For the purposes of this article, the multiple facets of humor reflected by these diverse definitions, disciplines, and cultures will be reviewed in order to demonstrate that humor competence is a pervasive life and language skill that needs to be taught to second or foreign language learners.

\section{PHILOSOPHICAL BEGINNINGS}

\section{The Western World}

Most humor research currently available in English is Western-centered, reviewing Ancient Greek, Roman, Middle-Ages and Renaissance theories of humor before focusing on modern European or North-American publications. In this vein of studies, Plato (427-347 BC) is unanimously quoted as the first significant writer to have philosophically analyzed humor well over two thousand years ago in Ancient Greece.

\section{Plato}

According to Attardo (1994) and Roeckelein (2002), Plato listed humor as one of the human emotions, ambivalent in its nature as a combination of pain and pleasure. The ridiculous, in Plato's view, was the lack of self-awareness. In powerful people, conceit was to be hated, but in feeble ones it was to be laughed at. He saw the grim side of humor as enjoyment at the misfortunes of others and condemned it on ethical grounds. In general, Plato's philosophy denounced excesses; therefore, laughter was to be avoided because it could make one lose rational control. In modern terms of second language and culture acquisition, these ideas were predecessors of the superiority theory of humor and point to the necessity of teaching the pragmatics of humor, particularly how not to offend others or avoid certain negative, destructive types of humor. 


\section{Aristotle}

Another great Ancient Greek philosopher, Aristotle (384-322 BC) also considered the ridiculous as something ugly which does not cause pain (Attardo, 1994). His view of humor, however, was more positive in that humor can stimulate the soul, as well as serve as a powerful rhetorical device, if used appropriately. In addition, Aristotle was the first to analyze the logical mechanisms of jokes and to comment on the humorous effects of the unexpected in metaphors, puns, and witticisms. He was also the first to contrast comedy and tragedy. Aristotle had a great influence on modern theories of humor not only in the Western tradition, as his work and that of other Ancient Greek thinkers had been translated into Arabic as well, and was familiar to Arab scholars throughout the Middle Ages (Attardo, 1994).

\section{The Orient}

Hence let us abandon Western centrism for a moment and glance even farther than Arabia, beyond the Great Wall of China. What early theories affect attitudes and beliefs about humor in China, Japan, Korea and other Asian countries, where millions of today's English language learners come from? Confucianism, Taoism, and Buddhism are the most significant ancient philosophical systems that need to be considered in order to understand the Asian outlook on the world, including humor.

\section{CONFUCIUS}

Resembling Plato's views on humor, Confucius (551-479 BC) advocated serious behavior and restraint, and denounced extreme emotions, such as laughter (Yue, 2010). While Euro-American attitudes to humor have considerably evolved since Plato to consider a sense of humor as a most desirable personal trait and a sign of intelligence (Wickberg, 1998), humor has not been respected in China for centuries, and is regarded as inferior, shallow type of aesthetic expression only fit for the uncouth and uneducated. Although Confucius himself was said to have had a sense of humor in his personal life, he once ordered the executions of several comedians for insulting royalties. Similarly, according to Yue (2011), Chinese people today feel ambivalent towards humor, privately enjoying a laugh as human beings, while still considering it a sign of immaturity, inappropriateness, and tasteless informality. Correspondingly, emotional restraint is also admired in Japan and many other Asian cultures, where humor is appropriate only in the company of close friends or family, drinking companions, or in formal humorous performances (Oda, 2006; Abe, 2006). The Asian code of business may not approve of the use of humor in the workplace as it may be considered too informal and impolite. A serious attitude is much admired. 


\section{Taoism and Buddhism}

Taoism, in contrast, embraced humor as a way to achieve emotional harmony and laughter as a natural human response, leading to unity with nature. Buddhism also encouraged humor as the force of enlightenment, and associated laughter with good fortune, sociability and success (Yue, 2010). Both philosophies promoted humorous expression for the benefits of self-improvement, open-mindedness and forbearance. This is more in tune with modern American attitudes towards humor and may help teach English language learners of Asian background the cultural differences in the appropriateness of tactful humor, which, unlike many Asian cultures, may be acceptable, even desirable in a wider range of situations and status of interlocutors in American culture.

\section{Sociocultural Functions of Humor}

In terms of second language teaching, it is important to consider the social functions humor fulfills in the target culture, which may be different from the students' native culture. As Robinson and Smith-Lovin's (2001) study showed, the functions of humor are not fixed, but depend on the relationships among interlocutors, their social context, and the content of the joke. The humor of a certain culture reflects its social phenomena, dominant beliefs, issues and cultural changes (Kuipers, 2008). For instance, while many humor studies (Crawford, 1995 and 2003; Hay 2000; Holmes, 2006; Kothoff, 2006; all as cited in Kuipers, 2008) have shown that men initiate more humor (in accordance with Coser's 1960 finding that people of higher status initiate more humor and get more laughs), more recent studies have begun to show women to initiate more jokes (Kothoff, 2006), mirroring the positively changing status of women in Western cultures. The humor of a culture also depends on the ideological, social and political foundations of a society, its government being repressive or democratic, and the respective power dynamics. Traditionally, humor has been found to provide relief from tension, promote social control, and enhance social cohesion (Kuipers, 2008).

\section{Relief}

The relief function of humor serves to release social tension but can also border on the psychological function of coping with stress. Booth-Butterfield, Booth-Butterfield and Wanzer's 2007 study is particularly relevant to college students' success. It showed how some American college students who were employed in jobs outside of class effectively managed the additional stress by using humor in communication. Moreover, another different population sample, fully employed adults, also showed identical correlations between their ability to cope with stress and their use of humor. In addition, for both samples job satisfaction was 
enhanced by their use of humor in communication. The positive effects were explained by the power of emotional expressivity, as well as the social attractiveness of humorous personalities, building stronger supportive networks.

\section{Social Control}

The social control function of humor is perhaps most clearly illustrated by what people laugh at, ridiculing traits or phenomena that are not desirable. These attitudes may be different in different cultures and second language learners will have to be introduced to what the target culture considers correct or advantageous in various spheres of human life. Morain (1991) recommends teaching international students about the social, working, language, and intellectual world of American culture to help them better understand American humor. Joking also serves to maintain or establish hierarchical relationships, where those of higher status joke more and their jokes are better accepted. People also tend to "joke down" more than "up" - for instance, Coser's classic 1960 study of joking relationships among hospital staff showed that doctors joked about the residents, residents joked about themselves or the nurses, and nurses joked about themselves or the patients and the patients' families.

\section{Social Cohesion}

In-group. In a more egalitarian environment though, the joking relationships would be different, working more toward group cohesion and delineating group boundaries (Kuipers, 2008). Inside jokes among friends increase their closeness, create an identity, and can break the ice with strangers. Of course some cultures may not use humor with strangers, so that will also have to be taught to second language learners. As interactionist approaches to humor state, humor is created in interaction, and the humorous intent of one speaker has to be accepted by the listeners for the humor to work. In the humorous mode, interlocutors can decrease social distance, have fun, and clarify positions on sensitive topics, where the ambiguity of humor always provides a way out for all participants.

Out-group. This cohesive function of humor has a negative side, however. It painfully excludes from the group those interlocutors who, like many international students, do not understand the jokes everyone else shares. Morain (1991) compared international and American students' appreciation of The New Yorker cartoons and found significant differences in understanding and perceived degree of funniness. The international students' sample included students of various English proficiency levels at a language learning program, who had been in the United States for short periods of time, as well as graduate students who had lived in the target culture for several years. Regardless of the length of time spent in the United States, the responses of both types of international students were very similar, demonstrating the inherent difficulty of understanding and appreciating the humor of another culture. 
Morain (1991) also interviewed in depth the graduate international students about their responses to the cartoons and to American humor in general. They unanimously agreed that humor was the most challenging feature of American culture for them. These mature, sophisticated graduate students spoke of the feelings of isolation and alienation they experienced because of their inability to understand the humor of their host culture. They felt stupid, and as if they did not belong in a group where everyone else was connected by shared laughter. Morain (1991) thus concludes that second language teaching needs to include exposure to authentic American humor and enriched cultural content, teaching the conventions of humor and techniques for analyzing humor, and finally opportunities for students to try out various types of their own jokes. These recommendations, as well as Attardo, Hempelmann and De Maio's 2002 taxonomy of the logical mechanisms of a joke formed the basis of Petkova's 2020 study, where a humor competence curriculum (Wulf, 2010) was designed, tried and tested in the English as a second language classroom.

Cultural divide or unifying factor? In a very interesting study with potential implications for the teaching of humor in another culture, Chiaro (2009) surveyed and interviewed 59 bilingual cross-cultural couples who had been together for over ten years about the use of humor in their daily relationship, such as the social and psycholinguistic aspects of humor, their language choices, attitudes, when they use humor and the type and functions of their verbal humor. Couples reported that they enjoy using their partner's language for humor, and feel annoyed when the partner does not make an effort to speak their language. Participants also felt excluded when their partner used his or her native language to joke, or was able to laugh at jokes, with other fellow native speakers.

The couples in Chiaro's (2009) study formed 24 language combinations; the participants' native languages were English, Albanian, Amharic, Arabic, Croatian, Czech, Danish, Dutch, Estonian, Filipino, Finnish, French, German, Greek, Malay, Japanese, Polish, Portuguese, Russian, Shona, Spanish, Tagalog, and Turkish. Refreshingly, this wide variety of languages includes many non-Western-European and non-Indo-European languages and cultures. Results showed that people of different linguistic backgrounds were very aware of the cultural differences in their humor. Interestingly, native English speakers consistently stated that their sense of humor, involving the use of irony, sarcasm, and understatement, was "better" than their partner's. They pointed out that the concept of understatement was unknown or non-existent in their partners' cultures (namely Italian and Hebrew, but probably many other cultures) and that irony and sarcasm were not understood by their partner's relatives and fellow-countrymen, who corrected their Italian and Hebrew when the native English speakers were trying to be funny in their partner's language. Non-English types of humor were considered less subtle, more naïve and juicier. English speakers also pointed out that their humor was dry, as if that were a more desirable or more sophisticated type of humor. 
On the other hand, the non-native English speakers in Chiaro's (2009) study initially were confused by their partners' ironic and sarcastic remarks and interpreted them as rude. After several years together, they reportedly learned to laugh at them or sometimes even produce them, although such humor continued to occasionally surprise them. In general, respondents considered their partner's different sense of humor a negative trait, which created tension between them and was characteristic of the partner's entire culture. These highly educated participants did understand, however, that not all differences in humor depended on culture, but were also determined by individual characteristics. They also realized that usually humor cannot be directly translated from one language to another.

Chiaro (2009) attempted to explain the superior attitudes of native English speakers with the fact that, as English has become the global lingua franca, couples with a native English speaking partner have elected to use English as their common language. If the other partner's English language proficiency was not up to par, that could negatively influence the impression of his or her humor. The fact that other speakers of their partner's language corrected the English speakers when they attempted to use irony or sarcasm in their second language could be attributed to the marginalization of the outsider, whose humor would only be acknowledged when he or she is completely accepted in the new culture. This notion is supported by Wulf's (2010) experience of telling his first successful joke in German: "My triumph was only slightly dampened when I was asked if I realized that I had said something funny" (p. 155). Bell (2006) also found that native speakers may tend to overly accommodate non-native speakers in humorous interaction with the effect of marginalizing them, expecting them not to understand.

In terms of teaching humor to second language learners, the most pertinent findings of Chiaro's (2009) research revealed that bilingual partners made a successful effort to learn each other's humor. Many participants said that after a few years, they were able to make humorous comments in their partner's language and in the style of humor preferred in his culture. Some explained how they even trained each other, watching funny videos together, translating and pausing as necessary to explain the jokes or their cultural background for each other. Consequently, this is a technique that has been directly implemented in the second language classroom by Petkova (2017), using authentic video material to enjoy and discuss the humor of the target culture (see also many other lesson plans on how to teach about humor in Rucynski, 2017). 


\section{CONCLUSION}

In the past several decades, an impressive body of research has been done in the linguistics and sociolinguistics of humor in a native language (Raskin, 1985; Giora, 1991; Attardo, 1994; Kothoff, 2003; Norrick, 2003; Crawford, 2003; Smith, 2009; Yus, 2003) and TESOL pragmatics (Boxer \& Pickering, 1995; Alcon Soler \& Martinez-Flor, 2008; Bardovi-Harlig, 1999; Cohen, 2005). More and more studies are also beginning to focus on the intersection of these two fields, namely humor in TESOL (Vega, 1990, Deniere, 1995, Schmitz, 2002; Tarone, 2000; Rucynski and Prichard, 2020). Even when they do look at this intersection, however, researchers often consider using humor only to teach vocabulary or language structure (Trachtenberg, 1979; Tocalli-Beller \& Swain, 2007), or to create a better classroom environment, relax the language learners and lower their affective filter (Medgyes, 2001). Finally, a refreshing wealth of lesson plans to teach with and about humor have recently been published by TESOL (Rucynski, 2017).

As far as using humor in spontaneous conversation in a foreign language, some researchers have explored the way English language learners themselves use humor in natural conversation (Bell, 2009; Davies, 2003) and made tentative recommendations for classroom instruction. Bell (2011) in particular draws attention to the importance and the need for further research in this area. The contributors to Rucynski and Prichard's 2020 edited book on bridging the humor barrier have attempted to answer this call to experiment with and test the effectiveness of humor competence instruction in the English language classroom. They offer multiple classroom strategies and different approaches to this important area of pragmatics in preparing English language learners for success in the real world.

With the advance of technology and the globalization of communication, business, travel and education, spontaneous interaction among native and non-native speakers of English is increasing in quantity and importance. Gone are the days when a professional may study English only to be able to read technical literature in that language. Today leisure, work, and study often include dealing with speakers of different languages, if not in person then by e-mail, telephone, text messages or videoconferences. Humor is an essential tool in business negotiation (Adelsward \& Oberg, 1998) and needed by many English language learners for success. If they feel marginalized in conversation because they do not understand some light-hearted remarks and are unable to respond quickly enough, who is supposed to help them? As the international students participating in Morain's (1991) study unanimously stated, failure to understand American humor made them feel isolated and alienated from the target culture. Classroom instruction, in the same way as it makes strides forward in the teaching of other areas of pragmatics, should not shy away from providing students with realistic humorous experiences and a safe place to experiment and get feedback on their own attempts at humor in a second or foreign language. 


\section{References}

Abe, G. (2006). A Ritual performance of laughter in Southern Japan. In J. M. Davis (ed.): Understanding humor in Japan (37-50). Detroit, MI: Wayne State University Press.

Adelsward, V. \& Oberg, B. (1998). The function of laughter and joking in negotiation activities. Humor: International Journal of Humor Research, 11, 411-429.

Alcon Soler, E. \& Martinez-Flor, A. (eds.) (2008). Investigating pragmatics in foreign language learning, teaching and testing. Clevedon, UK: Multilingual Matters.

Attardo, S. (1994). Linguistic theories of humor. Berlin, Germany: Mouton de Gruyter.

Attardo, S., Hempelmann, C. F. \& Di Maio, S. (2002). Script oppositions and logical mechanisms: Modeling incongruities and their resolutions. Humor, 15, 3-46.

Bardovi-Harlig, K. (1999). Exploring the interlanguage of interlanguage pragmatics: A research agenda for acquisitional pragmatics. Language Learning, 49, 677-713.

Bell, N. (2006). Interactional adjustments in humorous intercultural communication. Intercultural Pragmatics, 3(1), 1-28.

Bell, N. (2007). How native and non-native English speakers adapt to humor in intercultural interaction. Humor: International Journal of Humor Research, 20(1), $27-48$.

Bell, N. (2009). Learning about and through humor in the L2 classroom. Language Teaching Reasearch, 13, 241-258.

Bell, N. (2011). Humor scholarship and TESOL: Applying findings and establishing a research agenda. TESOL Quarterly, 45(1), 134-158.

Booth-Butterfield, M., Booth-Butterfield, S. \& Wanzer, M. (2007). Funny students cope better: Patterns of humor enactment and coping effectiveness. Communication Quarterly, 55, 299-315.

Boxer, D. \& Pickering, L. (1995). Problems in the presentation of speech acts in ELT materials: The case of complaints. ELT Journal, 49, 44-58.

Chiaro, D. (2009). Cultural divide or unifying factor? Humorous talk in the interaction of bilingual, cross-cultural couples. In N. Norrick \& D. Chiaro (eds.): Humor in interaction (211-231). Philadelphia, PA: John Benjamins Publishing Company.

Claire, E. (1984). What's so funny? A foreign student's introduction to American humor. Rochelle Park, NJ: Eardley.

Cohen, A. (2005). Strategies for learning and performing L2 speech acts. Intercultural pragmatics, 2, 275-301.

Coser, R. (1960). Laughter among colleagues: A study of the social functions of humor among the staff of a mental hospital. Psychiatry, 23(1), 81-95.

Crawford, M. (1995). Talking difference: On gender and language. London, UK: Sage. 
Crawford, M. (2003). Gender and humor in social context. Journal of Pragmatics, 35, 1413-1430.

Davies, C. E. (2003). How English-learners joke with native speakers: An intercultural sociolinguistic perspective on humor as collaborative discourse across cultures. Journal of Pragmatics, 35, 1361-1385.

Deniere, M. (1995). Humor and foreign language teaching. Humor: International Journal of Humor Research, 8, 285-298.

Giora, R. (1991). On the cognitive aspects of the joke. Journal of Pragmatics, 16, 465485.

Hay, J. (2000). Functions of humor in the conversations of men and women. Journal of Pragmatics, 32(6), 709-742.

Holmes, J. (2006). Sharing a laugh: Pragmatic aspects of humor and gender in the work-place. Journal of Pragmatics, 38(1), 26-50.

Kothoff, H. (2003). Responding to irony in different contexts: on cognition in conversation. Journal of Pragmatics, 35, 1387-1411.

Kothoff, H. (2006). Gender and humor: The state of the art. Journal of Pragmatics, 38 (1), 4-25.

Kuipers, G. (2008). The sociology of humor. In Raskin V. (ed.), The primer of humor research (361-398). Berlin, Germany: Mouton de Gruyter.

Lucas, T. (2005). Language awareness and comprehension through puns among ESL learners. Language Awareness, 14, 221-238.

Medgyes, P. (2001). How's this for fun? The role of humour in the ELT classroom and ELT teaching materials. In M. Bax \& C. Zwart (eds.): Reflections on language and language learning: In honor of Arthur van Essen (105-118). Philadelphia, PA: John Benjamins.

Morain, G. G. (1991). X-raying the international funny bone: A study exploring differences in the perception of humor across culture. Georgetown University Round Table on Languages and Linguistics, 397-408.

Norrick, N. (2003). Issues in conversational joking. Journal of Pragmatics, 35, 13331359.

Oda, S. (2006). Laughter and the traditional Japanese smile. In J. M. Davis (ed.): Understanding humor in Japan (15-26). Detroit, MI: Wayne State University Press.

Petkova, M. (2017). Funny Sitcom and Movie Scenes as a Springboard for StudentGenerated Role-Plays. In J. Rucynski (ed.): New ways in teaching with humor. Alexandria, VA: TESOL Press.

Petkova, M. (2020). Using diaries to research and develop humor competence in a second language. In J. Rucynski \& C. Prichard (eds.): Bridging the humor barrier: Humor competency training in English language teaching. Lanham, MD: Lexington Books.

Raskin, V. (1985). Semantic mechanisms of humor. Dordrecht, The Netherlands: Reidel. 
Robinson, D. \& Smith-Lovin, L. (2001). Getting a laugh: Gender, status and humor in task discussions. Social Forces, 80(1), 123-158.

Roeckelein, J. E. (2002). The psychology of humor. Westport, Connecticut: Greenwood Press.

Rucynski, J. (ed.) (2017). New ways in teaching with humor. Alexandria, VA: TESOLPress.

Rucynski, J. \& Prichard, C. (eds.) (2020). Bridging the humor barrier: Humor competency training in English language teaching. Lanham, MD: Lexington Books.

Schmitz, J. R. (2002). Humor as a pedagogical tool in foreign language and translation courses. Humor: International Journal of Humor Research, 15, 89-113.

Smith, M. (2009). Humor, unlaughter, and boundary maintenance. Journal of American Folklore, 122(484), 148-171.

Tarone, E. (2000). Getting serious about language play: Language play, interlanguage variation, and second language acquisition. In B. Swierzbin, F. Morris, M. E. Anderson, C. Klee \& E. Tarone (ed.), Social and cognitive factors in second language acquisition: Selected proceedings of the 1999 second language research forum (31-54). Somerville, MA: Cascadilla Press.

Tocalli-Beller, A., \& Swain, M. (2007). Riddles and puns in the ESL classroom: Adults talk to learn. In A. Mackey (ed.), Conversational interaction in second language acquisition: Empirical studies (143-167). Oxford, England: Oxford University Press.

Trachtenberg, S. (1979). Joke-telling as a tool in ESL. TESOL Quarterly, 13, 89-99.

Vega, G. (1990). Humor competence: The fifth component. Paper presented at the Annual Meeting of Teachers of English to Speakers of Other Languages. San Francisco, CA.

Wickberg, D. (1998). The senses of humor. Ithaca, NY: Cornell University Press.

Wulf, D. (2010). A humor competence curriculum. TESOL Quarterly, 44(1), 155-169.

Yue, X. D. (2010). Exploration of Chinese humor: Historical views, empirical findings, and critical reflections. Humor, 23(3), 403-420.

Yue, X. D. (2011). The Chinese ambivalence to humor: Views from undergraduates from Hong Kong and China. Humor, 24(4), 463-480.

Yus, F. (2003). Humor and the search for relevance. Journal of Pragmatics, 35, 12951331. 


\section{Марија Х. Петкова}

Универзитет у Пловдиву, Бугарска

\section{КОМПЕТЕНЦИЈА ЗА ХУМОР У ЕНГЛЕСКОМ КАО ДРУГОМ ИЛИ СТРАНОМ ЈЕЗИКУ}

\section{Резиме}

Развијање компетенције за хумор у оквиру енглеског као другог или страног језика је тешко, али је веома важно за успешну интеркултуралну комуникацију. Природа хумора и његове социокултурне функције чине компетенцију за хумор једном од тешкоћа са којом се чак и најбољи ученици често боре. Будући да су типови хумора и ставови према шали различити у различитим културама, а разумевање хумора захтева сложену комбинацију језичког и културног знања, наставници другог или страног језика треба да помогну својим ученицима у овој, често занемареној области прагматике. У друштвеним, академским и професионалним оквирима хумор може ублажити напетост, извршити социјалну контролу и појачати социјалну кохезију, правећи разлику ко припада или не припада одређеној групи. Како хумор може да функционише и као основа за културну поделу и као фактор који зближава, дошло је време да се у наставу другог или страног језика укључи нека врста подстицања и развоја компетенција за хумор. На основу истраживања о хумору и истраживања у настави енглеског као другог или страног језика, све више наставника почиње да експериментише, документује и оцењује резултате различитих стратегија и приступа настави са и о хумору у енглеском језику.

Кључне речи: хумор, компетенција за хумор, настава енглеског као другог језика, настава енглеског као страног језика, прагматика. 